\title{
Article \\ Sensitivity of Bistatic TanDEM-X Data to Stand Structural Parameters in Temperate Forests
}

\author{
Stefan Erasmi ${ }^{1,2, *}$, Malte Semmler ${ }^{1}$, Peter Schall ${ }^{3} \mathbb{C}$ and Michael Schlund ${ }^{1} \mathbb{D}$ \\ 1 Department of Cartography, GIS \& Remote Sensing, Institute of Geography, University of Göttingen, \\ D-37077 Göttingen, Germany; Malte.Semmler@biologie.uni-goettingen.de (M.S); \\ michael.schlund@uni-goettingen.de (M.S.) \\ 2 Thünen Institute of Farm Economics, Bundesallee 63, D-38116 Braunschweig, Germany \\ 3 Department of Silviculture and Forest Ecology of the Temperate Zones, Faculty of Forest Sciences and Forest \\ Ecology, University of Göttingen, D-37077 Göttingen, Germany; peter.schall@forst.uni-goettingen.de \\ * Correspondence: stefan.erasmi@thuenen.de
}

Received: 17 October 2019; Accepted: 10 December 2019; Published: 11 December 2019

check for updates

\begin{abstract}
Synthetic aperture radar (SAR) satellite data provide a valuable means for the large-scale and long-term monitoring of structural components of forest stands. The potential of TanDEM-X interferometric SAR (InSAR) for the assessment of forest structural properties has been widely verified. However, present studies are mostly restricted to homogeneous forests and do not account for stratification in assessing model performance. A systematic sensitivity analysis of the TanDEM-X SAR signal to forest structural parameters was carried out with emphasis on different strata of forest stands (location of the study site, forest type, and development stage). Forest structure was parameterized by forest height metrics and stem volume. Results show that X-band volume coherence is highly sensitive to the forest canopy. Volume scattering within the canopy is dependent on the vertical heterogeneity of the forest stand. In general, TanDEM-X coherence is more sensitive to forest vertical structure compared to backscatter. The relations between TanDEM-X volume coherence and forest structural properties were significant at the level of a single test site as well as across sites in temperate forests in Germany. Forest type does not affect the overall relationship between the SAR signal and the forests' vertical structure. The prediction of forest structural parameters based on the outcome of the sensitivity analysis yielded model accuracies between $15 \%$ (relative root mean square error) for Lorey's height and 32\% for stem volume. The global database of single-polarized bistatic TanDEM-X data provides an important source for mapping structural parameters in temperate forests at large scale, irrespective of forest type.
\end{abstract}

Keywords: TanDEM-X; X-band; single-polarization; forest structure; coherence; temperate forests

\section{Introduction}

There is a wide agreement in the scientific community today that forests play a major role in the global carbon cycle where forest degradation and conversion act as a source of carbon to the atmosphere and forest (re-) growth is a carbon sink [1]. Knowledge about the status and changes of forest structural parameters is important for the assessment of forest carbon stocks for national forest inventories in the context of reducing emissions from deforestation and forest degradation (REDD) and as a base input for the estimation of the forest above-ground biomass (AGB) which represents a key component in global carbon cycle models. Remote sensing has proven to be the most effective means to monitor the extent and qualitative as well as quantitative parameters of forests across wide areas from regional to global level $[2,3]$. In terms of the global carbon cycle, AGB is the most important forest variable. In general, it can be assessed from three different types of remote sensing data: passive optical, light detection 
and ranging (LiDAR), and synthetic aperture radar (SAR) data. A comprehensive summary of studies that aim at quantifying forest biomass from satellite sensors was compiled by [3]. AGB estimates from optical remote sensing data mostly rely on vegetation indices that parameterize the photosynthetic activity of vegetation. They imply a relationship between the foliage and the total AGB of a vegetation stand, which is further used to estimate AGB. Since the major part of AGB in forests is composed of non-photosynthetic (woody) components, such approaches imply high uncertainties. The major challenge in AGB mapping from optical data is the saturation of the signal after canopy closure which especially hampers the estimation of high-level AGB [4]. However, recent studies confirmed the general ability of optical systems like Landsat to map AGB at biomass levels around $70 \mathrm{Mg} / \mathrm{ha}$ [5].

The saturation problem can be overcome by sensors, which are able to penetrate through the canopy and interact with the forest constituents. For instance, LiDAR and interferometric SAR (InSAR) systems generally provide the necessary technique because they are able to penetrate the canopy of a forest and deliver information about the vertical structure of a forest stand. LiDAR data produce high-accuracy canopy height models ( $\mathrm{CHM})$ but the main drawback of LiDAR data to date is the limited coverage of large areas. However, InSAR data are available at regional to global scale from different spaceborne SAR missions and recently have shown their capability to estimate parameters of the three-dimensional structure in forest stands [6-9]. The coherence between two independent SAR acquisitions provides the key measure that can be related to parameters of the canopy. If other decorrelations than the volume decorrelation (such as temporal, signal to noise ratio, etc.) are minimized, it can be used to parameterize the vertical structure of a forest stand and thus provides a measure to directly relate to AGB. On a global scale, constellations with minimal temporal decorrelation are to date only available from the C-band mission SRTM [10] and the X-band mission TanDEM-X [11]. In general, three different approaches exist to estimate parameters of the vertical structure from InSAR acquisitions without temporal decorrelation: 1. physical modeling, 2. modeling of the canopy surface and subtraction of a terrain height from an available DTM, and 3. empirical modeling of the relationship between vertical structure and the SAR signal.

Physical models are usually based on an inversion of a model that aims at predicting the radar scattering of a natural surface from a complex set of object parameters that are retrieved from ground measurements of, for example, forest structural parameters. In general, the inversion of such models is only applicable to full-polarized InSAR (PolInSAR) data due to the problem of an unbalanced inversion function with more unknowns than knowns when only one single polarization is available [12]. Another constraint is that the maximum vegetation height that can be retrieved is limited by the penetration depth of the SAR signal which is a function of the wavelength and the structural properties of the forest stand [13]. This is the main reason why most applications of scattering and vertical structure model inversion rely on low frequency like L- or P-band PolInSAR data $[7,14]$. The effect of wavelength on retrieving forest height from the random volume over ground (RVOG), a two-layer and vertical structure model, and its inversion was recently demonstrated by [15] who compared X-, C-, and L-band and found that the RMSE of forest height inversion increased with increasing frequency. Nevertheless, single-polarized X-band InSAR data are used in scattering models under simplified assumptions or when ancillary data are available to replace missing scattering information of the ground layer [16-20]. Compared to these simplified scattering models, the second approach is dependent on the availability of ancillary data, e.g., a digital terrain model to derive information about the ground height. If this information is available, e.g., from national topographical surveys, the subtraction approach provides a simple but robust means to produce the InSAR height which is widely used as a proxy for the canopy height [21-23]. A comparison of the InSAR to the dominant (top) height of the canopy reveals that InSAR height underestimates the actual height of the forest [24,25]. Thus, the penetration depth of the SAR signal has to be accounted for when modeling the vertical structure and related AGB, especially when compared to other data sources [26]. Recent studies revealed the general discrepancies of the retrieved height values between the two modeling approaches and stated the importance of defining the term "height" in relation to the modeled and ground data [27]. 
Alternatively, empirical models are frequently used to estimate vertical stand structure parameters from the InSAR information. Here, the magnitude of the $X$-band coherence of TanDEM-X has proven its capabilities to predict Lorey's height, stem volume [21], and AGB [28]. In the following, the coherence refers to the magnitude of coherence. In addition to coherence, radar backscatter is known to be sensitive to stand structural parameters even if it does not allow for a direct estimation of forest height or biomass [29]. Ref. [30] demonstrated the sensitivity of X-band backscatter to vegetation density. On the other hand, ref. [31] compared different remote sensing sensors (C- and L-band SAR) and concluded that, in general, models based on coherence mostly outperform backscatter in terms of correlation strength with forest structural parameters. Other studies however confirmed the general ability of X-band backscatter to model biophysical variables of forest stands [32,33].

All three approaches imply benefits and limitations from the technical point of view. They underline the general ability of satellite-based InSAR data, especially low-frequency data like L- and P-band for the assessment of the vertical structure of forest stands that can be adapted to monitoring forest carbon stocks over large areas. However, the high-frequency TanDEM-X mission is the only spaceborne single-pass interferometer mission to date. Therefore, its potential to estimate forest structure parameters was frequently studied in the past and should be studied in more detail enabling large scale assessment of forest structures with TanDEM-X. Only a few studies investigated the transferability of methods to other environments and the impact of forest stratification on model performance [34]. The majority of studies was on boreal $[8,14,16,18,19,21,24]$ and tropical $[15,22,25,28,33]$ forests. In addition, the quality and accuracy of a model depend on the definition of the reference forest height that is investigated. Forest height is normally retrieved by aggregation of individual trees in a defined spatial area (e.g., sample plot), which depends on the type of aggregation and thus, forest height is an abstract statistical concept [35]. Therefore, in the present study, a detailed sensitivity analysis of X-band coherence to different forest structural parameters in temperate forests was carried out based on an empirical modeling approach. The aim was to better understand the factors that have an impact on the estimation of forest structural variables from X-band data, particularly the vertical structure of forests, and to propose sensor and environmental settings for the large scale assessment of forest resources based on X-band satellite data. The sensitivity analysis also included the backscatter coefficient of the X-band data in order to fully evaluate the relations between TanDEM-X bistatic data and forest structural parameters. It was carried out for three test sites in temperature forests in Germany and for TanDEM-X acquisitions during different seasons. This enabled an assessment of the transferability of the results between environments and under different conditions.

\section{Materials and Methods}

\subsection{Field Data}

The three study sites in Germany are situated along a gradient from northeast to southwest (Figure 1). They form part of the German Biodiversity Exploratories, a long-term and large-scale research project that aims at understanding the relationships between biodiversity, ecological processes, and land use and management changes [36]. The sites differ in landscape heterogeneity and dominant tree type (Table 1). All sites comprise pure as well as mixed deciduous and coniferous stands. The development stages of the managed stands range from pole wood to immature timber and mature timber where mature timber is dominating in two of three sites. 


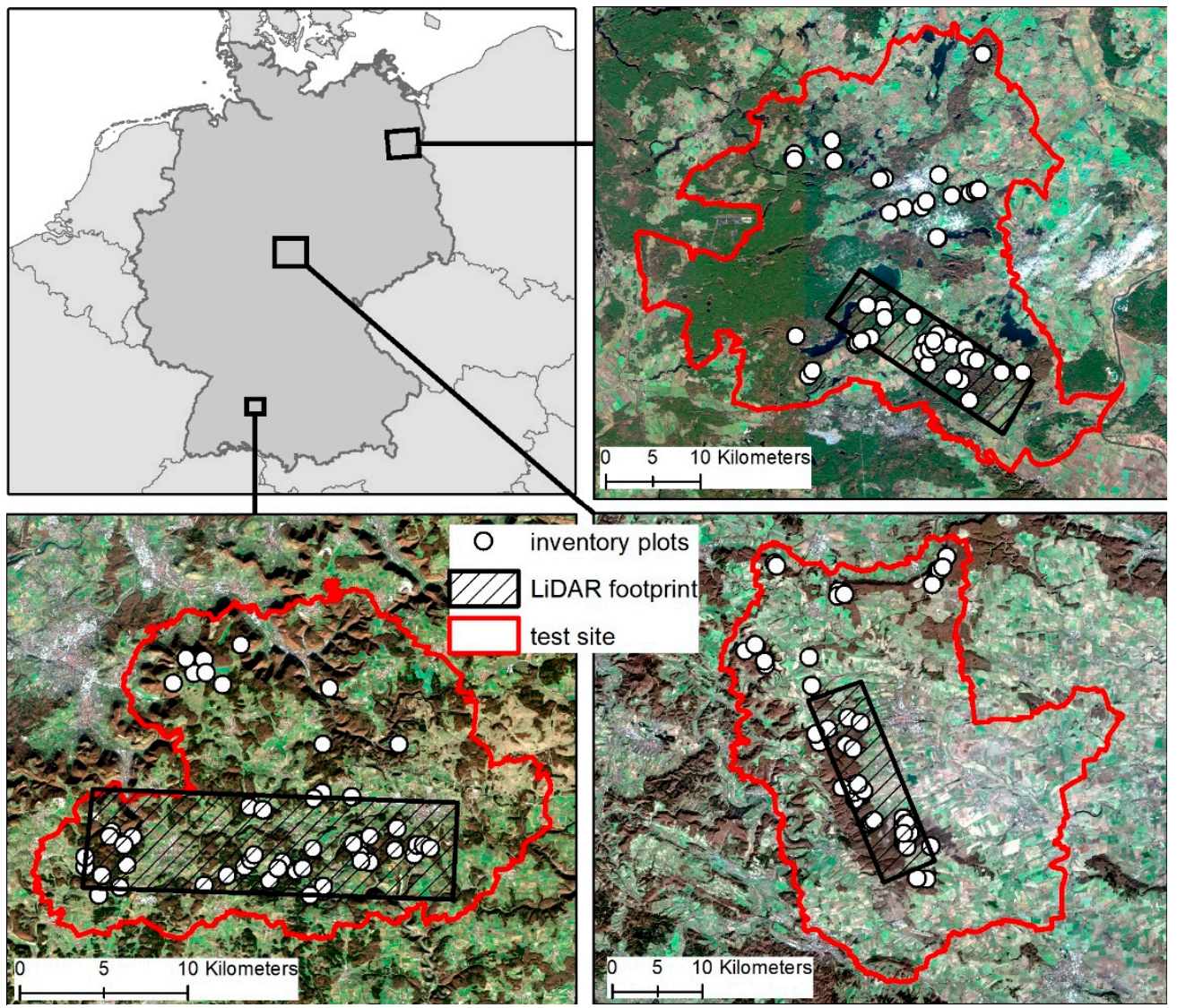

Figure 1. Overview of study sites with the location of forest inventory plots (upper right = Schwäbische Alb; lower left = Hainich; lower right = Schorfheide-Chorin; background: true color composites of winter acquisitions from Sentinel-2 images).

Table 1. Main characteristics of the study areas ( $n=$ all plots; $d=$ deciduous; $c=$ coniferous; $y=$ young; $m=$ mature).

\begin{tabular}{|c|c|c|c|c|c|}
\hline Study Area & $\begin{array}{l}\text { Center Long Lat } \\
\text { (WGS 1984) }\end{array}$ & Dominant Tree Species & Area $\left[\mathbf{k m}^{2}\right]$ & $\begin{array}{l}\text { No. of Plots } \\
(\mathrm{n} / \mathrm{d} / \mathrm{c} / \mathrm{m} / \mathrm{ym})\end{array}$ & $\begin{array}{c}\emptyset \text { No. of } \\
\text { Trees/Plot }\end{array}$ \\
\hline Schwäbische Alb (ALB) & $09.39 \mathrm{E} 48.43 \mathrm{~N}$ & $\begin{array}{c}\text { Fagus sylvatica }(43 \%) \\
\text { Picea abies }(38 \%)\end{array}$ & 422 & $\begin{array}{c}29 / 19 / 10 / \\
26 / 3\end{array}$ & 506 \\
\hline Hainich (HAI) & $10.45 \mathrm{E} 51.17 \mathrm{~N}$ & $\begin{array}{l}\text { Fagus sylvatica }(72 \%), \\
\text { Fraxinus excelsior }(11 \%)\end{array}$ & 1306 & $\begin{array}{c}43 / 39 / 4 / \\
35 / 8\end{array}$ & 597 \\
\hline Schorfheide-Chorin (SCH) & $13.78 \mathrm{E} 53.00 \mathrm{~N}$ & $\begin{array}{l}\text { Pinus sylvestris }(51 \%) \text {, } \\
\text { Fagus sylvatica }(34 \%)\end{array}$ & 1292 & $\begin{array}{c}32 / 20 / 12 / \\
31 / 1\end{array}$ & 374 \\
\hline
\end{tabular}

The Schorfheide-Chorin site covers an area of about $1292 \mathrm{~km}^{2}$ and is dominated by intensively managed pine monocultures and beech forests. The most common tree species in the area are Pinus sylvestris (51\%) and Fagus sylvatica (34\%). The landscape is characterized by the glacial forming process and has elevations ranging from 2 to $139 \mathrm{~m}$ a.s.l. The Hainich site covers around $1306 \mathrm{~km}^{2}$ and is part of the largest closed forest area of broad-leaved trees in Germany with dominating mixed beech forests. The most common tree species in the area are Fagus sylvatica (72\%) and Fraxinus excelsior (11\%). Elevation ranges from 165 to $532 \mathrm{~m}$ a.s.l. The size of the third site, Schwäbische Alb is approximately $422 \mathrm{~km}^{2}$. It is characterized by submontane to montane plateaus with elevations in the study site from 395 to $878 \mathrm{~m}$ a.s.l. Beech forests, mixed forests, and intensely managed spruce monocultures are typical for this area [36]. The most common tree species are Fagus sylvatica (43\%) and Picea abies (38\%).

Field data were collected between 2014 and 2016 for a total of 124 sample plots of one-hectare size $(100 \mathrm{~m} \times 100 \mathrm{~m})$ over the three study sites. The plots were selected using a stratified random sample 
with forest use intensity and soil depth as the main strata [36]. Within each plot, plant species and diameter at breast height $(d b h)$ measured in $1.3 \mathrm{~m}$ above ground, were recorded for all trees with a $d b h$ $>7 \mathrm{~cm}$ [37]. The plots were classified according to their forest type and development stage. Tree height was measured for a representative subsample of trees across frequently occurring tree species within a plot and was estimated for the remaining trees using stand height curves as described in [37]. From the individual field measurements within each plot, a number of stand parameters were calculated for each plot that directly or indirectly represent the forest height. Forest height in general describes the difference between the canopy height and the ground height within a forest stand. Different concepts for the definition of forest height exist. They are either related to the mean height of all trees within a defined area (mean tree height) or to the height of only a subset of the tallest trees within the stand (dominant tree height or top tree height). Other height parameters describe the distribution of tree height within the stand (e.g., measures of variance) and are used as proxies to evaluate the vertical structure/structural diversity of forest stands. Additionally, in forest management, a number of more comprehensive measures are derived from the height together with the trunk area and/or volume to assess the entire woody component of a tree.

In this study, arithmetic mean height $\left(h_{M}\right)$ and the 95th percentile of tree height $\left(h_{95}\right)$ were calculated from the entire sample of all measured trees within the plot area of one hectare. $h_{M}$ is a standard measure of mean height, whereas $h_{95}$ represents the top height and thus is more related to the forest canopy height of a stand [38]. In addition, the standard deviation of tree height $\left(h_{S D}\right)$ was used as a measure of the 3D-structure and variability within a stand. Lorey's height $\left(h_{L}\right)$ in $m$ is the mean tree height weighted by its basal area. It is often used in remote sensing studies since it provides a measure of forest height that is less affected by thinning and mortality of smaller trees [38]:

$$
h_{L}=\frac{\sum_{i=1}^{n}\left(B A_{i} * h_{i}\right)}{\sum_{i=1}^{n} B A_{i}}
$$

where $h_{i}$ is the height of tree $i, n$ the number of available trees, and $B A_{i}$ is the basal area of tree $i$. $B A$ is a common measure to describe the stand density taking into account the stem diameter [39]. It is defined as the trunk-cross sectional area in $\mathrm{m}^{2}$ per unit area:

$$
B A=\frac{\pi * \sum_{i=1}^{n} d b h_{i}^{2}}{4 * A}
$$

where $d b h$ is the diameter at breast height and $A$ is the plot area (i.e., one hectare in our study). Wood volume $(V O L)$ in $\mathrm{m}^{3} /$ ha was additionally included in the analysis. It was estimated as a function of $d b h$ and tree height using adapted empirical tree specific linear regressions for the dominating tree types in the study sites as described in [37]. Out of the 124 forest plots, 104 plots covered the footprints of the TanDEM-X data that were available for this study.

\subsection{Satellite Data}

Datasets from the bistatic TanDEM-X mission were used for this study. This mission operates two $\mathrm{X}$-band SAR satellites flying in close formation in order to acquire single-pass interferometric SAR data. The primary goal of the TanDEM-X mission was the generation of a global digital elevation model [11]. Both sensors of the TanDEM-X mission are able to transmit and receive the electromagnetic wave with a phased-array X-band antenna having a carrier frequency of $9.65 \mathrm{GHz}$ [40], which results in a wavelength of about $3.1 \mathrm{~cm}$. One sensor acts as a transmitter and receiver (monostatic/active) while the other only receives (bistatic/passive) the electromagnetic waves in the operational bistatic mode. However, during the mission lifetime, the sensors also operated in other, experimental modes and all datasets are available to the scientific community on request.

The TanDEM-X acquisitions that were used also contributed to the creation of the global TanDEM-X digital elevation model by the German Aerospace Center for the respective area. Thus, all scenes 
were acquired in horizontal polarization $(\mathrm{HH}$, transmit, and receive) and bistatic StripMap mode at a nominal resolution of about $3 \mathrm{~m}$. Data were delivered in a coregistered single look slant range complex (CoSSC) format. In total, eight acquisitions were used (Table 2). Two scenes were available for each of the three study areas, covering the winter and summer period in comparable sensor configurations. Two additional acquisitions for the core site Hainich were used to investigate the impact of varying acquisition parameters on the sensitivity to monitor structural parameters. Table 2 additionally lists the weather conditions during the overflight (mean air temperature and precipitation sum for the day of overflight) that were recorded at the closest weather station of the Climate Data Center of Deutscher Wetterdienst (DWD).

Table 2. Specifications for TanDEM-X CoSSC pairs $\left({ }^{*}=\right.$ additional acquisitions $)$ in the three study sites and weather conditions during overflight time (mean air temperature and precipitation sum for the day of overflight; HoA = height of ambiguity).

\begin{tabular}{|c|c|c|c|c|c|c|c|c|}
\hline Site & Date & Season & $\begin{array}{l}\text { Resolution } \\
\text { (az/rg) [m] }\end{array}$ & $\begin{array}{l}\text { Incidence } \\
\text { Angle }\left[{ }^{\circ}\right]\end{array}$ & $\begin{array}{c}\text { Eff. } \\
\text { Baseline }[\mathrm{m}]\end{array}$ & HoA $[\mathrm{m}]$ & $\begin{array}{l}\text { Precipitation } \\
(\mathrm{mm})\end{array}$ & $\begin{array}{c}\text { Temperature } \\
\left({ }^{\circ} \mathrm{C}\right)\end{array}$ \\
\hline \multirow{2}{*}{ ALB } & 04.09 .2011 & $\mathrm{~s}$ & $3.3 \times 2.8$ & 38.5 & 130.3 & 47.9 & 20.2 & 17.3 \\
\hline & 25.01 .2012 & $\mathrm{w}$ & $3.3 \times 2.8$ & 38.5 & 84.2 & 74.8 & 0 & -3 \\
\hline \multirow{4}{*}{ HAI } & 25.12 .2010 & * & $3.3 \times 2.4$ & 46.3 & 200.5 & 40.5 & 0 & -6.5 \\
\hline & 21.09.2011 & $\mathrm{s}$ & $3.3 \times 3.0$ & 36.2 & 128.2 & 44.5 & 0 & 11.9 \\
\hline & 22.02.2012 & w & $3.3 \times 3.0$ & 36.2 & 88.6 & 65.8 & 0 & 5.2 \\
\hline & 01.11 .2012 & $*$ & $3.3 \times 3.1$ & 34.8 & 162.7 & 33.7 & 1.5 & 5.4 \\
\hline \multirow{2}{*}{$\mathrm{SCH}$} & 28.01 .2011 & $\mathrm{w}$ & $3.3 \times 2.5$ & 44.6 & 189.5 & 40.5 & 0 & -4.1 \\
\hline & 09.07.2012 & $\mathrm{s}$ & $3.3 \times 2.5$ & 45.2 & 220.6 & 35.9 & 2.7 & 19.5 \\
\hline
\end{tabular}

\subsection{Processing of Satellite Data}

The TanDEM-X CoSSC data were processed in two separate workflows following the concept of the study to analyze the sensitivity of backscatter and coherence with respect to forest structure parameters.

The radar backscatter measures the amplitude of the scattered wave and was accounted for by calibrating the amplitude values to gamma naught $\left(\gamma^{0}\right)$ backscatter coefficients. Gamma naught represents the ratio between the incident power and the scattered power for a reference area that is perpendicular to the line of sight from the sensor to an ellipsoidal model of the ground surface [41]. The brightness of the scattered waves is affected by the terrain. Therefore, terrain flattening was performed to compensate for the local slope in the processing of $\gamma^{0}$ by dividing the backscatter by a factor for the local illuminated area:

$$
\gamma_{T}^{0}=K_{\gamma} \frac{\beta^{0}}{\hat{A}_{\gamma}},
$$

where $\beta^{0}$ is the backscatter in relation to the slant range of the SAR system, also referred to as the radar brightness. $K$ is a scalar calibration constant and $\hat{A}$ is a factor for the terrain corrected local illuminated area that is given by the ratio of the illuminated area in slant range to the plane that is perpendicular to the line of sight from the sensor [41]. The terrain flattened gamma naught values were multilooked with 5 to 6 looks in range and 6 looks in azimuth depending on the orbit and slant range position. The refined Lee filter [42] was applied to remove speckle effects using a window size of $7 \times 7$ pixels.

The magnitude of the interferometric coherence $(|\gamma|)$ describes the degree of correlation between two complex radar images [43]. It is a measure of quality for the phase measurement in interferometric SAR analysis (e.g., DEM generation). It is affected by instrument and acquisition parameters as well as topography and properties of the surface that is imaged, e.g., soil and vegetation structural parameters. Since the true coherence based on the expectation value is usually unknown, the interferometric coherence must be estimated with the mean value of neighboring pixels assuming ergodicity for the coherence [44]. In the present study, the coherence was estimated with a moving window of $9 \times 9$ pixels. In general, decorrelation of the coherence is caused by different, independent factors that are described in detail in [11]. For TanDEM-X, the temporal decorrelation can be neglected due to the 
almost simultaneous acquisitions. Decorrelation that was caused by other factors than the volume scattering of the vegetation was removed from the signal (see [26] for more details). As a result, the volume of coherence $\gamma_{V o l}$ can be retrieved as:

$$
\gamma_{V o l}=\frac{\gamma}{\gamma_{S N R}}
$$

where $\gamma_{S N R}$ is the signal-to-noise ratio (SNR) coherence. It is a function of the SNR of the individual channels of the bistatic acquisition and can be calculated from the NESZ pattern that is available for every single TanDEM-X dataset [26].

Both products-volume coherence and backscatter coefficient-were transformed to ground range in the cartographic reference system WGS1984 UTM Zone 32 (Schwäbische Alb, Hainich) and 33, respectively (Schorfheide-Chorin), and resampled to a uniform pixel size of $12 \mathrm{~m}$.

\subsection{Analysis}

Prior to the sensitivity analysis of the TanDEM-X data, a variance analysis (Mann-Whitney U test for two independent samples, Kruskal-Wallis test for more than two groups of data) was applied to the field data in order to test for the hypothesis that the distribution of the forest parameters is identical over the subsamples. The underlying assumption of this test was that the subsamples (e.g., forest type: deciduous vs. coniferous) of the investigated forest plots are representative and comparable and do not affect the overall relation between $\mathrm{X}$-band data and forest parameter.

The mean values of volume coherence $\gamma_{V o l}$, as well as $\gamma 0$ backscatter coefficient values, were then extracted from all available TanDEM- $X$ datasets for all pixels whose center coordinates fall inside the respective $100 \mathrm{~m} \times 100 \mathrm{~m}$ plot area. They were tested as independent variables in a univariate linear correlation model to analyze the relationship between the forest and SAR parameters:

$$
y_{i}=\alpha+\beta x_{i}+\varepsilon_{i}
$$

where $x_{i}$ is the SAR variable $\left(\gamma_{\text {Vol }} ; \gamma^{0}\right)$ and $y_{i}$ the forest parameter to be predicted for the plot $i, \alpha$ is the intercept (bias), $\beta$ is the slope, and $\varepsilon_{i}$ is the error term of the linear regression for that plot. A linear relation between the SAR variables and forest parameters was observed e.g., by $[45,46]$, and other studies. Since it requires a linear scaling of the input variables the gamma naught data were not logarithmically scaled to $\mathrm{dB}$ values.

The validation of results was based on the calculation of the Pearson correlation coefficient $r$. The overall significance of the linear models was estimated from an F-test and the definition of critical $p$-values at 99.9\%, 99\%, and 95\% significance level. For each test site, a TanDEM-X acquisition during wintertime and summertime was considered and the corresponding mean values for all plots were aggregated to a single variable for winter and summer respectively. In addition to the evaluation of all plots, the sample was split by forest type, study site, and development stage. Furthermore, for the Hainich test site, two additional TanDEM-X datasets were evaluated against further sensor characteristics (baseline, incidence angle, and height of ambiguity).

All relations were investigated for the InSAR volume coherence as well as for the backscatter coefficient as an independent variable and the five forest structural variables $\left(h_{95}, h_{L}, h_{M}, h_{S D}\right.$, and VOL) as dependent variables. All empirical models were evaluated based on a combination of strength, direction, and significance yielding a categorization of the model accuracy in six categories ranging from high to marginal significance with positive $(+)$ and negative $\left({ }^{*}\right)$ slopes of the regression line for the respective relation.

\section{Results}

A summary of the calculated plot attributes at the level of all 104 plot across the three study sites is given in Figure 2. The Kruskal-Wallis test revealed on the one hand that the distributions of all 
forest parameters, except $h_{M}$, were not statistically different between the three study sites. On the other hand, when separating all plots across the three sites by forest type (deciduous vs. coniferous), the Mann-Whitney-U test pointed out that all parameters except $h_{M}$ and VOL showed significantly different distributions. The same applies to a stratification of the whole dataset by the development stage (young vs. mature stands). Here, the distribution of all forest parameters was significantly different between the development stages. In general, the sample of forest stands across the three sites reflected a large heterogeneity of forest structural characteristics and management intensity. In the following, the sensitivity of the SAR signal for variations in these forest structural parameters was tested over the gradient of all three sites as well as for the different stratification schemes (forest type, development stage). This enabled a comprehensive assessment of the relations between the TanDEM-X signal and forest structural parameters.
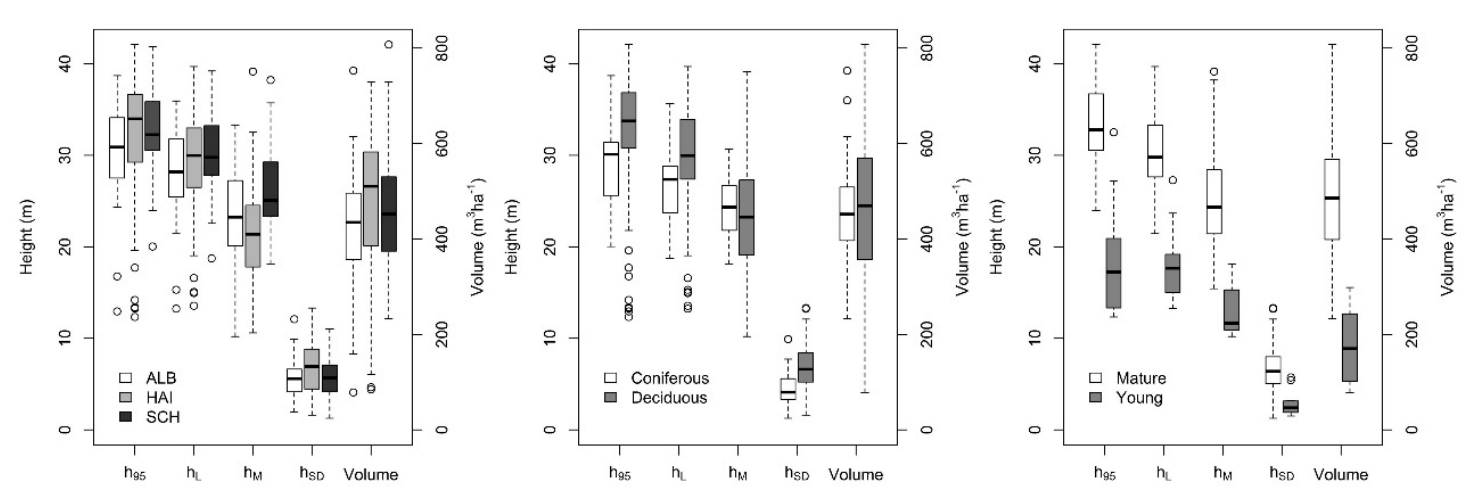

Figure 2. Summary of the forest plot parameters stratified by study area (left), forest type (middle) and development stage (right) $\left(h_{95}=95\right.$ th percentile of tree height $[\mathrm{m}], h_{L}=$ Lorey's height $[\mathrm{m}], h_{M}=$ mean height $[\mathrm{m}], h_{S D}=$ standard deviation of height $[\mathrm{m}], V O L=$ tree stand volume [m3/ha]) Black line $=$ median, boxes $=$ lower and upper quartile ( $50 \%$ of the values), whiskers $=1.5$ interquartile range, points $=$ outliers.

\subsection{Sensitivity Analysis across All Three Test Sites}

The summary of the linear models for all available plots (Table 3) reveals that the relationships between TanDEM-X acquisitions and forest height parameters were more significant during wintertime compared to summertime. Furthermore, the volume coherence of the two complex bistatic images yielded considerably higher significant relationships in terms of $r$ - and $p$-values compared to the backscatter coefficient of the single (master) TanDEM- $X$ image. Coherence showed highly significant linear relations to all tested forest parameters for the winter acquisitions and to $h_{95}, h_{L}$, and $h_{S D}$ for the summer acquisition. The relation between volume coherence and forest parameters was always negative, i.e., an increase in the forest variable is associated with a decrease in coherence. On the contrary, the slope of the regression line for the models that used backscatter as independent variable is positive for all significant relations, i.e., an increase in the forest variable was accompanied by an increase in the backscatter coefficient. However, only $h_{S D}$ showed a significant positive trend. When the sample was split by forest type, deciduous forests, in general, were more significant in winter whereas the significance for the relations between forest variables and volume coherence in coniferous forests was higher in summer. The slopes of the linear empirical models were comparable between the different forest types for the same forest parameter (Figure 3a). It is worth noting that the general significance of the models did not improve after forest type stratification. Comparable effects were observed for the stratification of the forest plots by the development stage (compare Figure $3 b$ for the relation between volume coherence and $h_{95}$ for young and mature forests). However, the detailed analysis of the stratification by the development stage was restricted to this site since the sample for young forest stands was small compared to mature forest stands and the majority of young stands occurred in one test site (HAI). 
Table 3. Summary of model significance for the estimation of forest parameters from TanDEM-X volume coherence $\left(\gamma_{V o l}\right)$ and backscatter coefficient $\left(\gamma^{0}\right)$ from all available field plots across the three study sites and with stratification by forest type ( $\mathrm{dec}=$ deciduous, $\mathrm{con}=$ coniferous $)$.

\begin{tabular}{|c|c|c|c|c|c|c|c|}
\hline \multirow[b]{2}{*}{ Parameter } & \multirow[b]{2}{*}{ Season } & \multicolumn{3}{|c|}{$\gamma_{V o l}$} & \multicolumn{3}{|c|}{$\gamma^{0}$} \\
\hline & & $\begin{array}{c}\text { All } \\
n=104\end{array}$ & $\begin{array}{c}\text { Dec } \\
n=78\end{array}$ & $\begin{array}{c}\text { Con } \\
n=26\end{array}$ & $\begin{array}{c}\text { All } \\
n=104\end{array}$ & $\begin{array}{c}\text { Dec } \\
n=78\end{array}$ & $\begin{array}{c}\text { Con } \\
n=26\end{array}$ \\
\hline \multirow{2}{*}{$h_{95}$} & $\mathrm{~s}$ & $* * *$ & $* *$ & $* * *$ & $\circ$ & $\circ$ & $\circ$ \\
\hline & $\mathrm{w}$ & $* * *$ & $* * *$ & $* *$ & $\circ$ & $\circ$ & $\circ$ \\
\hline \multirow{2}{*}{$\mathrm{h}_{\mathrm{L}}$} & $\mathrm{s}$ & $* * *$ & $* *$ & $* * *$ & $\circ$ & $\circ$ & $\circ$ \\
\hline & $\mathrm{w}$ & $* * *$ & $* * *$ & $* *$ & $\circ$ & $\circ$ & $\circ$ \\
\hline \multirow{2}{*}{$\mathrm{h}_{\mathrm{M}}$} & $\mathrm{s}$ & $\circ$ & $\circ$ & $* * *$ & $\circ$ & $\circ$ & $\circ$ \\
\hline & $\mathrm{w}$ & $* * *$ & $* * *$ & * & $\circ$ & $\circ$ & $\circ$ \\
\hline \multirow{2}{*}{$\mathrm{h}_{\mathrm{SD}}$} & $\mathrm{S}$ & $* * *$ & $* * *$ & ** & + & $\circ$ & $\circ$ \\
\hline & $\mathrm{w}$ & $* * *$ & $* * *$ & * & +++ & $\circ$ & $\circ$ \\
\hline \multirow{2}{*}{ VOL } & $\mathrm{s}$ & $\circ$ & $\circ$ & $\circ$ & * & * & $\circ$ \\
\hline & $\mathrm{w}$ & $* * *$ & $* * *$ & $\circ$ & $\circ$ & $\circ$ & $\circ$ \\
\hline+++ & \multirow{7}{*}{\multicolumn{7}{|c|}{$\begin{array}{l}\text { highly significant positive }(p<0.001) \\
\text { highly significant negative }(p<0.001) \\
\text { significant positive }(p<0.01) \\
\text { significant negative }(p<0.01) \\
\text { marginally significant positive }(p<0.05) \\
\text { marginally significant negative }(p<0.05) \\
\text { not significant }\end{array}$}} \\
\hline$* * *$ & & & & & & & \\
\hline++ & & & & & & & \\
\hline$* *$ & & & & & & & \\
\hline+ & & & & & & & \\
\hline * & & & & & & & \\
\hline 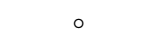 & & & & & & & \\
\hline
\end{tabular}

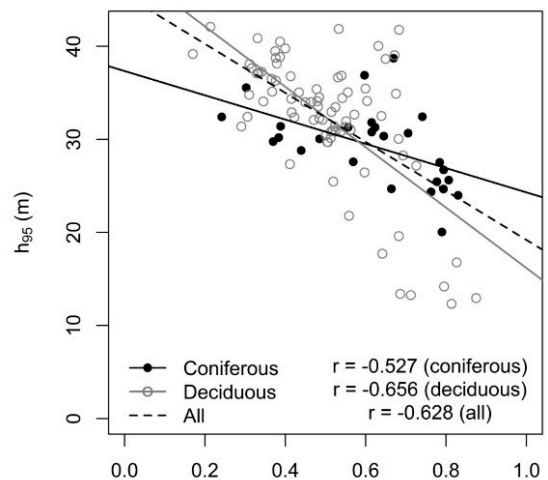

(a)

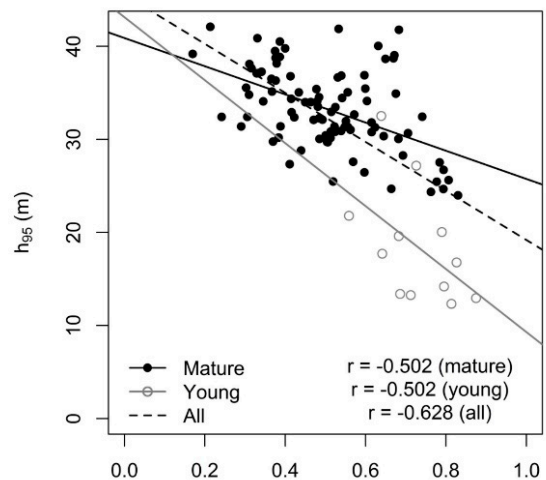

(b)

Figure 3. Scatterplot between volume coherence $\left(\gamma_{V o l}\right)$ of TanDEM-X acquisition during the winter period and top tree height (h95) (a) for the different forest types and (b) for the different development stages across all three study sites.

In contrast to coherence, the models that are based on backscatter did not reveal any significant relations, except for a weak negative relation between backscatter and $V O L$ in deciduous forests.

\subsection{Sensitivity Analysis at the Level of the Study Site}

Subsequently to the investigation of the whole set of 104 plots, the sample was divided by the study site in order to confirm the higher-level relations. The results also indicate that at the site level, TanDEM-X acquisitions during wintertime resulted in higher significant relationships to forest height parameters compared to summertime in all three sites (Table 4). In general, volume coherence yielded considerably better results in terms of model significance compared to backscatter in Schwäbische Alb and Hainich. The study site Schorfheide-Chorin showed opposing results with higher significant relations for backscatter compared to coherence as an independent variable. The slope direction for the 
significant models, again, showed contrasting trends for coherence and backscatter, e.g., the relation between volume coherence and the observed forest structural parameters was negative and positive for most forest parameters and the backscatter coefficient. The slopes of the trend lines for the linear empirical models were comparable between the three study sites as can be seen for the relation between volume coherence and $h_{95}$ in Figure 4 . In general, all forest parameters showed at least one highly significant relation to one of the SAR variable in one of the three sites. However, weaker sensitivity was observed for $h_{M}$ compared to other forest structural parameters.

Table 4. Summary of model significance for the estimation of forest parameters from TanDEM-X volume coherence $\left(\gamma_{V o l}\right)$ and backscatter coefficient $\left(\gamma^{0}\right)$ for the three study sites Schwäbische Alb (ALB), Hainich (HAI), and Schorfheide-Chorin (SCH) without stratification.

\begin{tabular}{|c|c|c|c|c|c|c|c|}
\hline & & \multicolumn{3}{|c|}{$\gamma_{V o l}$} & \multicolumn{3}{|c|}{$\gamma^{0}$} \\
\hline & & ALB & HAI & $\mathrm{SCH}$ & ALB & HAI & $\mathrm{SCH}$ \\
\hline Parameter & Season & $n=29$ & $n=43$ & $\mathrm{n}=32$ & $n=29$ & $n=43$ & $\mathrm{n}=32$ \\
\hline \multirow{2}{*}{$\mathrm{h}_{95}$} & $\mathrm{~s}$ & $* *$ & $* *$ & $\circ$ & $\circ$ & $\circ$ & ++ \\
\hline & $w$ & $* * *$ & $* * *$ & $\circ$ & $\circ$ & $\circ$ & +++ \\
\hline \multirow{2}{*}{$\mathrm{h}_{\mathrm{L}}$} & $\mathrm{s}$ & * & $* *$ & $\circ$ & $\circ$ & $\circ$ & ++ \\
\hline & $w$ & $* * *$ & $* * *$ & $\circ$ & $\circ$ & $\circ$ & +++ \\
\hline \multirow{2}{*}{$\mathrm{h}_{\mathrm{M}}$} & $\mathrm{s}$ & $\circ$ & $\circ$ & $\circ$ & $\circ$ & $\circ$ & $\circ$ \\
\hline & $\mathrm{w}$ & $\circ$ & $* * *$ & $\circ$ & $\circ$ & $\circ$ & + \\
\hline \multirow{2}{*}{$\mathrm{h}_{\mathrm{SD}}$} & $\mathrm{s}$ & $* * *$ & $* * *$ & * & $\circ$ & + & +++ \\
\hline & $\mathrm{w}$ & $* * *$ & $* * *$ & $* * *$ & $\circ$ & + & +++ \\
\hline \multirow{2}{*}{ VOL } & $\mathrm{s}$ & $\circ$ & $\circ$ & $\circ$ & $* *$ & $\circ$ & $\circ$ \\
\hline & $\mathrm{w}$ & $\circ$ & $* * *$ & $\circ$ & * & $\circ$ & $\circ$ \\
\hline+++ & \multirow{7}{*}{\multicolumn{7}{|c|}{$\begin{array}{l}\text { highly significant positive }(p<0.001) \\
\text { highly significant negative }(p<0.001) \\
\text { significant positive }(p<0.01) \\
\text { significant negative }(p<0.01) \\
\text { marginally significant positive }(p<0.05) \\
\text { marginally significant negative }(p<0.05) \\
\text { not significant }\end{array}$}} \\
\hline$* * *$ & & & & & & & \\
\hline++ & & & & & & & \\
\hline$* *$ & & & & & & & \\
\hline+ & & & & & & & \\
\hline * & & & & & & & \\
\hline - & & & & & & & \\
\hline
\end{tabular}

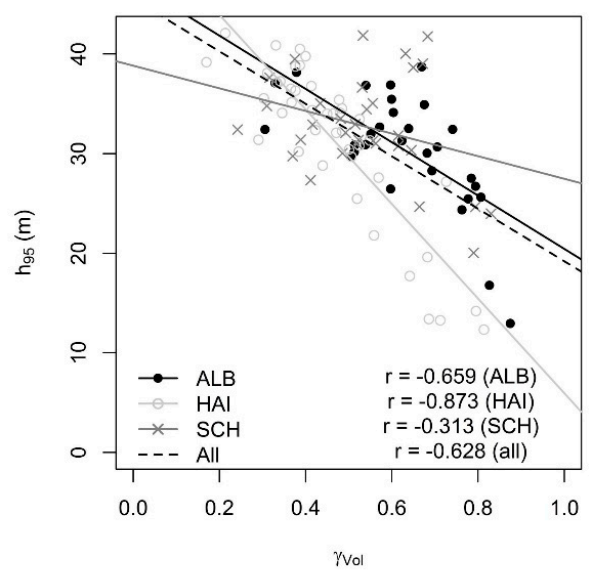

Figure 4. Scatterplot between volume coherence $\left(\gamma_{V o l}\right)$ of TanDEM-X acquisition during the winter period and top tree height $\left(\mathrm{h}_{95}\right)$ for the three study sites Schwäbische Alb (ALB), Hainich (HAI), and Schorfheide-Chorin (SCH).

At the site level, a further stratification in two classes (mature vs. young forests) was carried out in order to investigate the effect of the development stage of the forest stands as a categorical variable 
in the sensitivity analysis. Since the number of samples for young forests was too small for the sites Schwäbische Alb $(n=3)$ and Schorfheide-Chorin $(n=1)$, only the Hainich site could be considered for this part of the analysis. In general, the separation by development stage leads to a decrease in model significance based on volume coherence for mature stands compared to all stands in Hainich (Table 5). This is more frequently observed for the acquisitions during the summertime $\left(h_{95}, h_{L}, h_{S D}\right)$ compared to the winter scenes $(V O L)$. Young stands only sparsely show any significant relations between volume coherence and plot parameters, the overall sensitivity is extremely low compared to the consideration of all plots. A scatterplot of the volume coherence against $h_{95}$ clearly demonstrates a clustering in the distribution of forest parameters and the coherence values with high coherence and low top tree height in young stands and lower coherence and higher top heights in mature stands (Figure 5). However, the slope of the trend line is almost identical for both groups of the development stage.

Table 5. Summary of model significance for the estimation of forest parameters from TanDEM- $X$ volume coherence $\left(\gamma_{\mathrm{Vol}}\right)$ and backscatter coefficient $\left(\gamma^{0}\right)$ for the study site Hainich with stratification by development stage (mature = mature forests, young = young forests; full legend see Table 3 ).

\begin{tabular}{|c|c|c|c|c|c|c|c|}
\hline & & \multicolumn{3}{|c|}{$\gamma_{V o l}$} & \multicolumn{3}{|c|}{$\gamma^{0}$} \\
\hline & & All & Mature & Young & All & Mature & Young \\
\hline Parameter & Season & $n=43$ & $\mathrm{n}=35$ & $n=8$ & $n=43$ & $n=35$ & $n=8$ \\
\hline \multirow{2}{*}{$\mathrm{h}_{95}$} & $\mathrm{~s}$ & $* *$ & $\circ$ & $\circ$ & $\circ$ & $\circ$ & $\circ$ \\
\hline & $\mathrm{w}$ & $* * *$ & $* * *$ & $\circ$ & $\circ$ & + & $\circ$ \\
\hline \multirow{2}{*}{$\mathrm{h}_{\mathrm{L}}$} & $\mathrm{s}$ & $* *$ & $\circ$ & $\circ$ & $\circ$ & $\circ$ & $\circ$ \\
\hline & w & $* * *$ & $* * *$ & $\circ$ & $\circ$ & + & $\circ$ \\
\hline \multirow{2}{*}{$\mathrm{h}_{\mathrm{M}}$} & $\mathrm{s}$ & $\circ$ & $\circ$ & $\circ$ & $\circ$ & $\circ$ & $\circ$ \\
\hline & $\mathrm{w}$ & $* * *$ & $* * *$ & * & $\circ$ & $\circ$ & $\circ$ \\
\hline \multirow{2}{*}{$\mathrm{h}_{\mathrm{SD}}$} & $\mathrm{s}$ & $* * *$ & $* *$ & $\circ$ & + & ++ & $\circ$ \\
\hline & $\mathrm{w}$ & $* * *$ & $\circ$ & $\circ$ & + & + & $\circ$ \\
\hline \multirow{2}{*}{ VOL } & $\mathrm{s}$ & $\circ$ & $\circ$ & $\circ$ & $\circ$ & $\circ$ & $\circ$ \\
\hline & $\mathrm{w}$ & $* * *$ & * & $* *$ & $\circ$ & $\circ$ & $\circ$ \\
\hline+++ & \multirow{7}{*}{\multicolumn{7}{|c|}{$\begin{array}{l}\text { highly significant positive }(p<0.001) \\
\text { highly significant negative }(p<0.001) \\
\text { significant positive }(p<0.01) \\
\text { significant negative }(p<0.01) \\
\text { marginally significant positive }(p<0.05) \\
\text { marginally significant negative }(p<0.05) \\
\text { not significant }\end{array}$}} \\
\hline$* * *$ & & & & & & & \\
\hline++ & & & & & & & \\
\hline$* *$ & & & & & & & \\
\hline+ & & & & & & & \\
\hline * & & & & & & & \\
\hline$\circ$ & & & & & & & \\
\hline
\end{tabular}

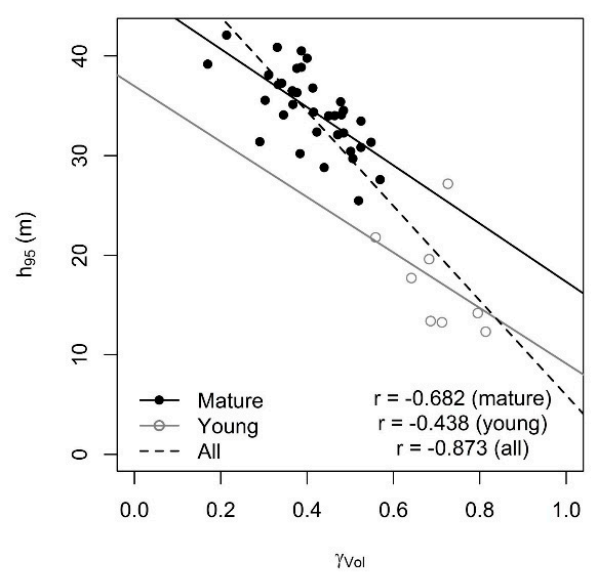

Figure 5. Scatterplot between volume coherence $\left(\gamma_{V o l}\right)$ of TanDEM-X acquisition during the winter period and top tree height (h95) for the different development stages in Hainich. 
Considering the backscatter coefficient, in part, it is positively impacted by stratification, however, only a few significant relations are observed and they are only present for mature stands. Young stands do not display any significant relation between backscatter and forest structural parameters, but due to the small sample size, the results for this category should be treated carefully.

\subsection{Impact of Sensor Parameters on Relation between SAR Signal and Forest Structural Parameters}

With regard to data availability and based on the results from the previous sections (weak relations between forest parameters and backscatter), the impact of varying sensor parameters on the relation between SAR data and forest structural parameters was only investigated based on volume coherence data for the study site Hainich. Four TanDEM-X scenes with variations in sensor parameters (baseline, incidence angle, and height of ambiguity) and time of acquisition (two in wintertime, one in late summer, and one in autumn) were available (Table 6). Even if this small set does not allow for a systematic evaluation of the impact of sensor parameters, a number of qualitative remarks seem feasible.

Table 6. Summary of model significance for the estimation of forest parameters from TanDEM-X volume coherence $\left(\gamma_{V o l}\right)$ for the study site Hainich without stratification for all available StripMap acquisitions (HoA = height of ambiguity).

\begin{tabular}{|c|c|c|c|c|}
\hline \multirow{2}{*}{$\begin{array}{c}n=43 \\
\text { Date }\end{array}$} & \multicolumn{4}{|c|}{$\gamma_{V o l}$} \\
\hline & 20101225 & 20110921 & 20120222 & 20121101 \\
\hline day of year & 359 & 264 & 53 & 306 \\
\hline baseline (m) & 200.47 & 128.15 & 88.60 & 162.70 \\
\hline incidence angle $\left(^{\circ}\right)$ & 46.30 & 36.18 & 36.18 & 34.80 \\
\hline HoA (m) & 40.5 & 44.5 & 65.8 & 33.7 \\
\hline$h_{95}$ & $* * *$ & $* *$ & $* * *$ & $* *$ \\
\hline $\mathrm{h}_{\mathrm{L}}$ & $* * *$ & $* *$ & $* * *$ & * \\
\hline$h_{M}$ & * & $\circ$ & $* * *$ & $\circ$ \\
\hline $\mathrm{h}_{\mathrm{SD}}$ & $* * *$ & $* * *$ & $* * *$ & $* * *$ \\
\hline VOL & $* *$ & $\circ$ & $* * *$ & $\circ$ \\
\hline$* * *$ & \multirow{4}{*}{\multicolumn{4}{|c|}{$\begin{array}{l}\text { highly significant negative }(p<0.001) \\
\text { significant negative }(p<0.01) \\
\text { marginally significant negative }(p<0.05) \\
\text { not significant }\end{array}$}} \\
\hline$* *$ & & & & \\
\hline * & & & & \\
\hline$\circ$ & & & & \\
\hline
\end{tabular}

The two acquisitions in wintertime, in general, show higher sensitivity to the forest structural parameters compared to the other two TanDEM-X scenes in summer and autumn. Amongst these two winter acquisitions, the scene of 22 February 2012 with the smallest baseline and highest height of ambiguity yielded highly significant results over all observed plot parameters. In comparison, the autumn acquisition performs worst. In general, all acquisitions are sensitive to the main structural parameters that describe the canopy height $\left(h_{L}, h_{95}\right)$ and vertical structure of forest stands $\left(h_{S D}\right)$.

\section{Discussion}

The study investigated the sensitivity of X-band SAR data to structural components of forest stands in temperate forests of different composition and management intensity in three different landscapes. Despite the heterogeneity within and between the sites, the overall structure of the forest plots regarding the observed forest parameters in the three sites was comparable (Figure 2). Thus, the patterns of the empirical models from one site were assumed to be reproducible in the other sites. Empirical models were tested for the entirety of all plots across the different sites (Table 3). In general, the relation between volume coherence and the investigated forest parameters was negative, both for the complete sample and at the level of the study site. Volume coherence decreased when the value of the forest structural parameter that is related to the height of the forest stand increased [24,47]. The highest sensitivity of the $\mathrm{X}$-band was found for the relationship between coherence and the forest 
parameters that parameterize the canopy height $\left(h_{L}, h_{95}\right)$ and the vertical component of the forest structure $\left(h_{S D}\right)$ which can be used as a proxy for the vertical layering of the stands [48]. On the other hand, factors that describe the overall composition of the stand (mean tree height, and volume) had a weaker impact on the SAR signal. Increasing forest top tree height, in general, leads to more penetration of the SAR signal into the canopy and an increase in scattering and thus decorrelation of the phase. This has been observed also for X-band in forests [24,49]. Based on this fundamental relation, the general sensitivity of coherence for forest structural parameters was confirmed in different studies, e.g., for stem volume [21,50], Lorey's height [21,51], and tree height [47,52].

In contrast to volume coherence, higher X-band backscatter values coincided with higher values of the respective forest parameter. In general, the relations between the backscatter coefficient and forest structural parameters were found to be considerably weaker compared to coherence for the TanDEM-X data. This is in accordance with [28] who investigated the relations between forest variables (AGB) and TanDEM-X coherence as well as backscatter. [53] confirmed that in general, X-band backscatter does not contribute to AGB and stem volume estimations. One explanation for this could be the X-band backscatter signal saturation, which was reported even at low levels of AGB [33]. The following discussion thus focuses on the results based on the volume coherence.

Highly significant correlations between volume coherence and forest structural parameters were observed for both summer and winter acquisitions of TanDEM-X (Table 3). Overall, the winter acquisitions lead to more significant empirical relationships for the entire dataset as well as for deciduous forests. This was also observed by [54] for the assessment of the vertical structure from TanDEM-X InSAR data. Our results confirmed that leaf-off conditions are favorable in deciduous forests for monitoring structural parameters with $X$-band coherence where penetration is higher and thus the volume coherence contains more information about vertical structure compared to leaf-on conditions [54]. Accordingly, coniferous stands were not affected by season or, in parts, even show a higher significance for summer acquisitions of TanDEM-X. The impact of the seasonal conditions on the relation between coherence at C-band and forest structural parameters was also investigated by [50]. They suggested that the absolute level of coherence contributes significantly to the strength of the correlation between coherence and stem volume. A lower level of coherence was in general associated with summer/autumn observations and higher levels to winter observations [50], thus, the results confirmed the above mentioned seasonal behavior of X-band volume coherence. Exceptions from this general trend are supposed to be attributed to anomalies in weather conditions, e.g., frozen/unfrozen conditions in winter [53] or presence of water on stem, leaves or in the atmosphere [26]. Note that also the baseline and the respective height of ambiguity affects the absolute level of coherence.

The stratification of the entire sample of 104 forest plots by different categorical variables at the stand level (forest type, study site, and development stage) was carried out to investigate the validity of the found relations in other environments under similar conditions. The main outcome, here, was that a separation by forest type (deciduous/coniferous) did not improve the overall relations between volume coherence and forest structural parameters and that all significant relations were negative, independent of forest type (Table 3). This is in opposition to other findings that underlined the impact of stratification on the relation between SAR data and forest parameters and even showed opposing trends in models after separation of the total sample [34,52]. A general criticism of applying models across different forest types was issued by [29] who claimed that scatterplots of SAR variables against forest structural variables show clusters within the distribution that are related to the strata and thus, the statistical relationship might not reflect the actual relation within each cluster. In contrast, the stratification by forest type (deciduous/coniferous) did not result in different distributions and relations in our study. This is in line with other studies revealing that different tree types do not have a major effect on modeling forest structural parameters, at least during leaf-on conditions [55,56].

The stratification of the total sample by study site indicated that the general relations between coherence and forest parameters are reproducible at the site level (Table 4). The slopes of the trend lines were comparable between the sites, indicating that the site as a categorical variable did not contribute 
to a clustering of the data distribution (Figure 4). [34] confirms a significant impact of the site on the model performance for two substantially different forests in Spain and Denmark. However, in our study, the Schorfheide site indicated generally less significant relationships compared to the other sites. This could be based on the fact that only one young forest plot was available in Schorfheide and thus, forest height was generally at the same level across the plots. Another explanation for the weaker performance in Schorfheide is the lower tree density. More open forests lead to a higher penetration of the X-band and thus to a more diffuse scattering. On the contrary, the open stands in Schorfheide show less saturation of the X-band backscatter, which is in accordance with [34]. This leads to a higher sensitivity of backscatter to forest structural parameters at this site.

A different effect was observed for the stratification by the development stage (Table 5). In the present study, the separation in young and mature forests clearly indicated two clusters in the scatterplot of volume coherence against forest parameters. The slope of the trend line between the two categories was identical but the trend of mature forests showed a notable bias compared to young forests (Figure 5). It was found that, in general, the separation by development stage had the most obvious effect on the sensitivity of the X-band to forest structural parameters. This is in line with [25] who reported a significant impact of both slope and bias on the relation between InSAR height parameters and stem volume when the sample was stratified by stand parameters.

The comparison of TanDEM-X single-polarized data over one study site for different acquisition configurations underlined the advantage of leaf-off conditions for X-band based forest assessments and the impact on the relation between $X$-band coherence and forest parameters that describe the vertical structure at the stand level (Table 6). The height of ambiguity in three out of four TanDEM-X acquisitions was close to the top tree height of the study site. Best results in terms of model significance were achieved with a height of ambiguity that is considerably above the top tree height $(65.8 \mathrm{~m})$. If the height of ambiguity is in the range of the top tree height, the phase cannot be unwrapped without ambiguity [57], on the other hand, very small baselines and higher height of ambiguity lead to limitations in sensitivity of the phase to forest vertical structure $[45,58,59]$. Thus, the optimal height of ambiguity for forest vertical structure assessment from X-band InSAR data is above the maximum stand height and should not exceed $100 \mathrm{~m}$ [45].

Based on the sensitivity analysis of single-pol TanDEM- $X$ coherence to forest structural parameters, empirical linear models were tested in terms of the ability to predict the forest parameters (Figure 6). Most accurate predictions were achieved for parameters that define the upper canopy and the vertical structure of the stand $\left(h_{95}, h_{L}\right)$ compared to parameters that express the overall composition of the forest at the stand level $\left(h_{M}\right.$. VOL). The accuracy in terms of the coefficient of determination and the $R M S E_{p}$ is comparable to other studies based on single-pol X-band InSAR data that used ancillary data for the ground phase $[21,58]$ or evaluated physical models for the prediction of forest structural parameters [20]. 

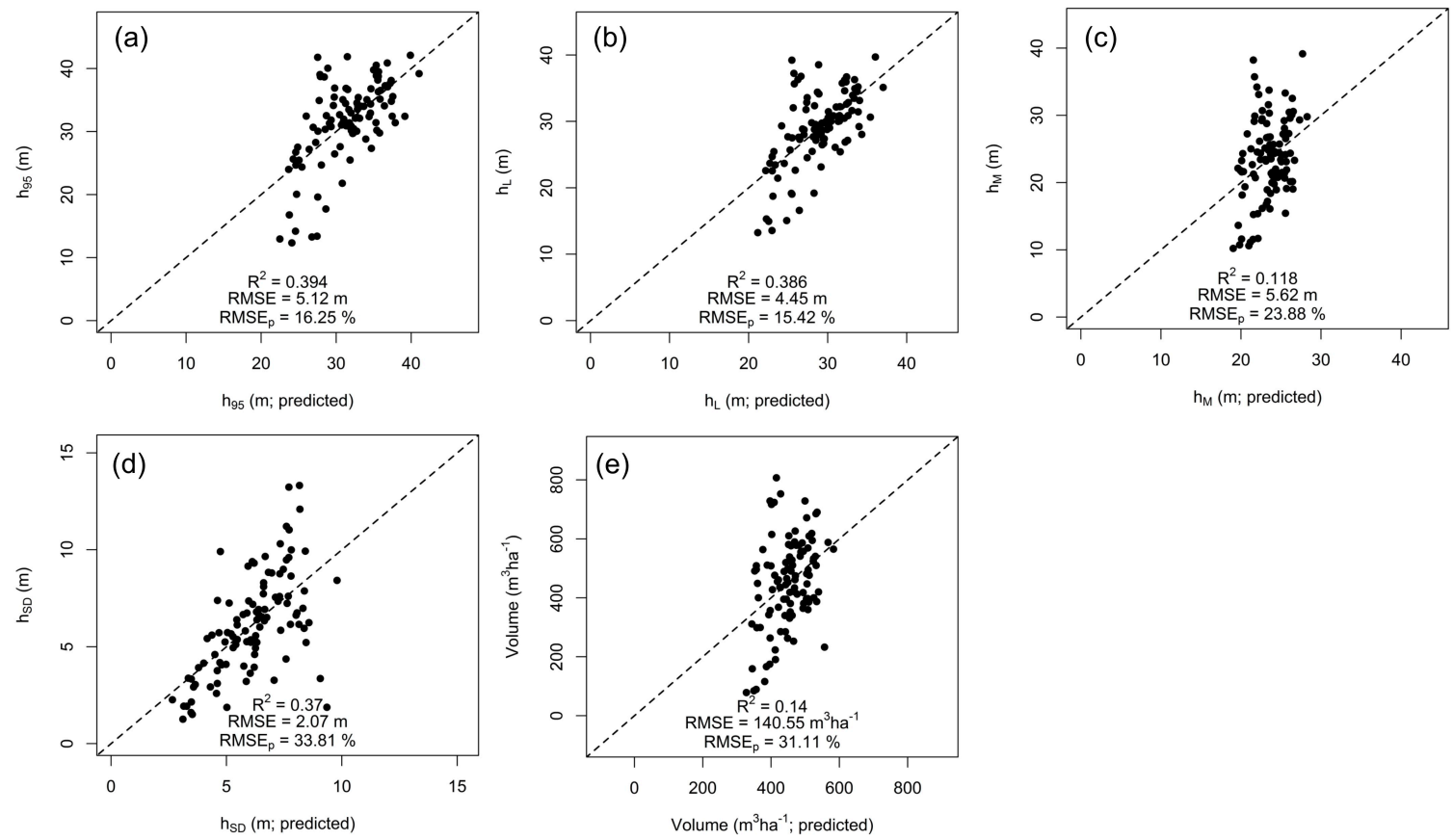

Figure 6. Comparison of predicted and observed forest structure parameters based on volume coherence from TanDEM-X single-pol winter acquisitions for (a) 95th percentile of tree height, (b) Lorey's height, (c) arithmetic mean height, (d) standard deviation of height and (e) wood volume.

\section{Conclusions}

The aim of this study was to investigate the validity and comparability of the relations between the $\mathrm{X}$-band signal of TanDEM-X single-polarized bistatic data and different measures of the forest structure under different environmental and sensor settings. The results confirm that volume coherence of the $\mathrm{X}$-band is highly sensitive to the upper canopy of forest stands (top tree height). In spite of the high saturation of the X-band in forest stands, the SAR-backscatter was shown to be sensitive to structural components of the forest in stands with lower tree density. However, in general, TanDEM-X coherence is superior to backscatter as a predictor of forest vertical structure.

The sensitivity of TanDEM-X coherence to forest structural properties could not only be demonstrated for a single test site but also across a set of sites that represent a gradient of forest types, land-use intensity, and management across the biome of temperate forests in Germany. In particular, it could be shown that forest type does not affect the overall relationship between the SAR signal and the forest's vertical structure. As a conclusion, TanDEM- $X$ volume coherence provides a robust and valuable means for mapping and modeling forest structural parameters in temperate forests with regard to monitoring carbon stocks at large scale, irrespective of the forest type. At present, TanDEM-X is the only satellite system that enables routinely single-pass InSAR acquisitions. The operational lifetime of TanDEM-X already exceeded in 2015 but currently, it is still operating and acquiring a new coverage of bistatic InSAR data for the monitoring of global land resources. Data continuity of spaceborne bistatic X-band SAR systems would enable consistent monitoring of forest resources and forest degradation. The planned HRWS (high-resolution-wide-swath) X-band mission of DLR [60] with its multi-static design is a promising concept to extend the X-band capabilities for earth observation.

Author Contributions: Conceptualization, S.E. and M.S. (Michael Schlund); data curation, M.S. (Malte Semmler) and P.S.; formal analysis, M.S. (Malte Semmler); funding acquisition, S.E.; investigation, S.E. and M.S. (Michael Schlund); methodology, M.S. (Michael Schlund); project administration, S.E.; writing-original draft, S.E.; writing-review and editing, S.E., M.S. (Malte Semmler), P.S., and M.S. (Michael Schlund). 
Funding: This work was funded by the Federal Ministry of Economic Affairs and Energy (BMWi) for the project BoDEM under Grant No. 50EE1509. We acknowledge support for publishing this work by the Open Access Publication Funds of the University of Göttingen.

Acknowledgments: TanDEM-X data used within this work were provided by DLR. We thank the managers of the three Exploratories, Kirsten Reichel-Jung, Katrin Lorenzen, Martin Gorke, and all former managers for their work in maintaining the plot and project infrastructure; Jule Mangels for giving support through the central office, Michael Owonibi for managing the central database, and Markus Fischer, Eduard Linsenmair, Dominik Hessenmller, Daniel Prati, Ingo Schning, Francois Buscot, Ernst-Detlef Schulze, Wolfgang W. Weisser, and the late Elisabeth Kalko for their role in setting up the Biodiversity Exploratories project. The work has been (partly) funded by the DFG Priority Program 1374 "Infrastructure-Biodiversity-Exploratories" (DFG-Refno. KL894/21-2 and KL894/21-3). Fieldwork permits were issued by the responsible state environmental offices of Baden-Württemberg, Thüringen, and Brandenburg (according to $\$ 72 \mathrm{BbgNatSchG).} \mathrm{We} \mathrm{are} \mathrm{grateful} \mathrm{to} \mathrm{Paul} \mathrm{Magdon} \mathrm{for} \mathrm{assisting} \mathrm{in}$ field data interpretation.

Conflicts of Interest: The authors declare no conflict of interest.

\section{References}

1. Schimel, D. Forests in the Global Carbon Cycle. In Challenges and Opportunities for the World's Forests in the 21st Century; Fenning, T., Ed.; Springer: Dordrecht, The Netherlands, 2014; pp. 231-239.

2. Gibbs, H.K.; Brown, S.; Niles, J.O.; Foley, J.A. Monitoring and estimating tropical forest carbon stocks: Making REDD a reality. Environ. Res. Lett. 2007, 2, 1-13. [CrossRef]

3. Rodríguez-Veiga, P.; Wheeler, J.; Louis, V.; Tansey, K.; Balzter, H. Quantifying Forest Biomass Carbon Stocks From Space. Curr. For. Rep. 2017, 3, 1-18. [CrossRef]

4. Goetz, S.; Dubayah, R. Advances in remote sensing technology and implications for measuring and monitoring forest carbon stocks and change. Carbon Manag. 2011, 2, 231-244. [CrossRef]

5. Huang, H.; Liu, C.; Wang, X.; Zhou, X.; Gong, P. Integration of multi-resource remotely sensed data and allometric models for forest aboveground biomass estimation in China. Remote Sens. Environ. 2019, 221, 225-234. [CrossRef]

6. Balzter, H. Forest mapping and monitoring with interferometric synthetic aperture radar (InSAR). Prog. Phys. Geogr. 2001, 25, 159-177. [CrossRef]

7. Neumann, M.; Ferro-Famil, L.; Reigber, A. Estimation of Forest Structure, Ground, and Canopy Layer Characteristics from Multibaseline Polarimetric Interferometric SAR Data. IEEE Trans. Geosci. Remote Sens. 2010, 48, 1086-1104. [CrossRef]

8. Pinto, N.; Simard, M.; Dubayah, R. Using InSAR Coherence to Map Stand Age in a Boreal Forest. Remote Sens. 2013, 5, 42-56. [CrossRef]

9. Santoro, M.; Shivdenko, A.; McCallum, I.; Askne, J.; Schmullius, C. Properties of ERS-1/2 coherence in the Siberian boreal forest and implications for stem volume retrieval. Remote Sens. Environ. 2007, 106, 154-172. [CrossRef]

10. van Zyl, J.J. The Shuttle Radar Topography Mission (SRTM): A breakthrough in remote sensing of topography. Acta Astronaut. 2001, 48, 559-565. [CrossRef]

11. Krieger, G.; Moreira, A.; Fiedler, H.; Hajnsek, I.; Werner, M.; Younis, M.; Zink, M. TanDEM-X: A Satellite Formation for High-Resolution SAR Interferometry. IEEE Trans. Geosci. Remote Sens. 2007, 45, 3317-3341. [CrossRef]

12. Freeman, A.; Durden, S.L. A Three-Component Scattering Model for Polarimetric SAR Data. IEEE Trans. Geosci. Remote Sens. 1998, 36, 963-973. [CrossRef]

13. Kugler, F.; Schulze, D.; Hajnsek, I.; Pretzsch, H.; Papathanassiou, K. TanDEM-X Pol-InSAR Performance for Forest Height Estimation. IEEE Trans. Geosci. Remote Sens. 2014, 52, 6404-6422. [CrossRef]

14. Praks, J.; Antropov, O.; Hallikainen, M.T. LIDAR-Aided SAR Interferometry Studies in Boreal Forest: Scattering Phase Center and Extinction Coefficient at X- and L-Band. IEEE Trans. Geosci. Remote Sens. 2012, 50, 3831-3843. [CrossRef]

15. Khati, U.; Singh, G.; Kumar, S. Potential of Space-Borne PolInSAR for Forest Canopy Height Estimation Over India-A Case Study Using Fully Polarimetric L-, C-, and X-Band SAR Data. IEEE J. Sel. Top. Appl. Earth Obs. Remote Sens. 2018, 11, 2406-2416. [CrossRef]

16. Toraño Caicoya, A.; Kugler, F.; Hajnsek, I.; Papathanassiou, K.P. Large-Scale Biomass Classification in Boreal Forests with TanDEM-X Data. IEEE Trans. Geosci. Remote Sens. 2016, 54, 5935-5951. [CrossRef] 
17. Qi, W.; Dubayah, R.O. Combining Tandem-X InSAR and simulated GEDI lidar observations for forest structure mapping. Remote Sens. Environ. 2016, 187, 253-266. [CrossRef]

18. Askne, J.; Fransson, J.; Santoro, M.; Soja, M.; Ulander, L. Model-Based Biomass Estimation of a Hemi-Boreal Forest from Multitemporal TanDEM-X Acquisitions. Remote Sens. 2013, 5, 5574-5597. [CrossRef]

19. Askne, J.I.; Persson, H.J.; Ulander, L.M. On the Sensitivity of TanDEM-X-Observations to Boreal Forest Structure. Remote Sens. 2019, 11, 1644. [CrossRef]

20. Schlund, M.; Magdon, P.; Aumann, C.; Eaton, B.; Erasmi, S. Canopy height estimation with TanDEM-X in temperate and boreal forests. Int. J. Appl. Earth Obs. Geoinf. 2019, 82. [CrossRef]

21. Karila, K.; Vastaranta, M.; Karjalainen, M.; Kaasalainen, S. Tandem-X interferometry in the prediction of forest inventory attributes in managed boreal forests. Remote Sens. Environ. 2015, 259-268. [CrossRef]

22. Schlund, M.; Poncet, F.; Kuntz, S.; Boehm, H.D.V.; Hoekman, D.H.; Schmullius, C. TanDEM-X elevation model data for canopy height and aboveground biomass retrieval in a tropical peat swamp forest. Int. J. Remote Sens. 2016, 37, 5021-5044. [CrossRef]

23. Kellndorfer, J.; Walker, W.; Pierce, L.; Dobson, C.; Fites, J.A.; Hunsaker, C.; Vona, J.; Clutter, M. Vegetation height estimation from Shuttle Radar Topography Mission and National Elevation Datasets. Remote Sens. Environ. 2004, 93, 339-358. [CrossRef]

24. Sadeghi, Y.; St-Onge, B.; Leblon, B.; Simard, M. Canopy Height Model (CHM) Derived from a TanDEM-X InSAR DSM and an Airborne Lidar DTM in Boreal Forest. IEEE J. Sel. Top. Appl. Earth Obs. Remote Sens. 2016, 9, 381-397. [CrossRef]

25. Solberg, S.; Hansen, E.H.; Gobakken, T.; Naesset, E.; Zahabu, E. Biomass and InSAR height relationship in a dense tropical forest. Remote Sens. Environ. 2017, 166-175. [CrossRef]

26. Schlund, M.; Baron, D.; Magdon, P.; Erasmi, S. Canopy penetration depth estimation with TanDEM-X and its compensation in temperate forests. ISPRS J. Photogramm. Remote Sens. 2019, 147, 232-241. [CrossRef]

27. Abdullahi, S.; Kugler, F.; Pretzsch, H. Prediction of stem volume in complex temperate forest stands using TanDEM-X SAR data. Remote Sens. Environ. 2016, 174, 197-211. [CrossRef]

28. Schlund, M.; Poncet, F.; Kuntz, S.; Schmullius, C.; Hoekman, D.H. TanDEM-X data for aboveground biomass retrieval in a tropical peat swamp forest. Remote Sens. Environ. 2015, 158, 255-266. [CrossRef]

29. Woodhouse, I.H.; Mitchard, E.T.A.; Brolly, M.; Maniatis, D.; Ryan, C.M. Radar backscatter is not a 'direct measure' of forest biomass. Nat. Clim. Chang. 2012, 2, 556. [CrossRef]

30. Bernhard, E.M.; Twele, A.; Martinis, S. The Effect of Vegetation Type and Density on X-Band SAR Backscatter after Forest Fires. PFG Photogramm. Fernerkund. Geoinf. 2014, 4, 275-285. [CrossRef]

31. Hyyppä, J.; Hyyppä, H.; Inkinen, M.; Engdahl, M.; Linko, S.; Zhu, Y.H. Accuracy comparison of various remote sensing data sources in the retrieval of forest stand attributes. For. Ecol. Manag. 2000, 128, 109-120. [CrossRef]

32. Dobson, M.C.; Ulaby, F.T.; Pierce, L.E.; Sharik, T.L.; Bergen, K.M.; Kellndorfer, J.; Kendra, J.R.; Li, E.; Lin, Y.C.; Nashashibi, A.; et al. Estimation of Forest Biophysical Characteristics in Northem Michigan with SIR-C/X-SAR. IEEE Trans. Geosci. Remote Sens. 1995, 33, 877-895. [CrossRef]

33. Englhart, S.; Keuck, V.; Siegert, F. Aboveground biomass retrieval in tropical forests-The potential of combined X- and L-band SAR data use. Remote Sens. Environ. 2011, 115, 1260-1271. [CrossRef]

34. Joshi, N.; Mitchard, E.T.A.; Brolly, M.; Schumacher, J.; Fernández-Landa, A.; Johannsen, V.K.; Marchamelo, M.; Fensholt, R. Understanding 'saturation' of radar signals over forests. Sci. Rep. 2017, 7, 1-11. [CrossRef] [PubMed]

35. Aulinger, T.; Mette, T.; Papathanassion, K.P.; Hajnsek, I.; Heurich, M.; Krzystek, P. Validation of Heights from Interferometric SAR and LIDAR over the Temperate Forest Site "Nationalpark Bayerischer Wald". In Proceedings of the 2nd International Workshop POLinSAR 2005, Frascati, Italy, 17-21 January 2005; Lacoste, H., Ed.; ESA Publications Div: Neuilly-sur-Seine, Noordwijk, 2005; p. 11.

36. Fischer, M.; Bossdorf, O.; Gockel, S.; Hänsel, F.; Hemp, A.; Hessenmöller, D.; Korte, G.; Nieschulze, J.; Pfeiffer, S.; Prati, D.; et al. Implementing large-scale and long-term functional biodiversity research: The Biodiversity Exploratories. Basic Appl. Ecol. 2010, 11, 473-485. [CrossRef]

37. Schall, P.; Schulze, E.D.; Fischer, M.; Ayasse, M.; Ammer, C. Relations between forest management, stand structure and productivity across different types of Central European forests. Basic Appl. Ecol. 2018, 32, 39-52. [CrossRef]

38. Nakai, T.; Sumida, A.; Kodama, Y.; Hara, T.; Ohta, T. A comparison between various definitions of forest stand height and aerodynamic canopy height. Agric. For. Meteorol. 2010, 150, 1225-1233. [CrossRef] 
39. Kershaw, J.A., Jr.; Ducey, M.J.; Beers, T.W.; Husch, B. Forest Mensuration, 5th ed.; John Wiley \& Sons: Chichester, UK; Hoboken, NJ, USA, 2017.

40. Pitz, W.; Miller, D. The TerraSAR-X Satellite. IEEE Trans. Geosci. Remote Sens. 2010, 48, 615-622. [CrossRef]

41. Small, D. Flattening Gamma: Radiometric Terrain Correction for SAR Imagery. IEEE Trans. Geosci. Remote Sens. 2011, 49, 3081-3093. [CrossRef]

42. Lee, J.S.; Grunes, M.R.; de Grandi, G. Polarimetric SAR Speckle Filtering and Its Implication for Classification. IEEE Trans. Geosci. Remote Sens. 1999, 37, 2363-2373.

43. Moreira, A.; Prats-Iraola, P.; Younis, M.; Krieger, G.; Hajnsek, I.; Papathanassiou, K. A Tutorial on Synthetic Aperture Radar. IEEE Geosci. Remote Sens. Mag. 2013, 1, 6-43. [CrossRef]

44. Touzi, R.; Lopes, A.; Bruniquel, J.; Vechon, P.W. Coherence Estimation for SAR Imagery. IEEE Trans. Geosci. Remote Sens. 1999, 37, 135-149. [CrossRef]

45. Lindgren, N.; Persson, H.J.; Nyström, M.; Nyström, K.; Grafström, A.; Muszta, A.; Willén, E.; Fransson, J.E.S.; Ståhl, G.; Olsson, H.; et al. Improved Prediction of Forest Variables Using Data Assimilation of Interferometric Synthetic Aperture Radar Data. Can. J. Remote Sens. 2017, 43, 374-383. [CrossRef]

46. Karjalainen, M.; Kankare, V.; Vastaranta, M.; Holopainen, M.; Hyyppä, J. Prediction of plot-level forest variables using TerraSAR-X stereo SAR data. Remote Sens. Environ. 2012, 117, 338-347. [CrossRef]

47. Santoro, M.; Askne, J.; Smith, G.; Fransson, J.E.S. Stem volume retrieval in boreal forests from ERS-1/2 interferometry. Remote Sens. Environ. 2002, 81, 19-35. [CrossRef]

48. McElhinny, C.; Gibbons, P.; Brack, C.; Bauhus, J. Forest and woodland stand structural complexity: Its definition and measurement. For. Ecol. Manag. 2005, 218, 1-24. [CrossRef]

49. Treuhaft, R.; Gonzalves, F.; dos Santos, J.R.; Keller, M.; Palace, M.; Madsen, S.N.; Sullivan, F.; Graca, P.M. Tropical-Forest Biomass Estimation at X-Band from the Spaceborne TanDEM-X Interferometer. IEEE Geosci. Remote Sens. Lett. 2015, 12, 239-243. [CrossRef]

50. Koskinen, J.T.; Pulliainen, J.; Hyyppä, J.M.; Engdahl, M.E.; Hallikainen, M.T. The Seasonal Behavior of Interferometric Coherence in Boreal Forest. IEEE Trans. Geosci. Remote Sens. 2001, 39, 820-829. [CrossRef]

51. Vastaranta, M.; Niemi, M.; Karjalainen, M.; Peuhkurinen, J.; Kankare, V.; Hyyppä, J.; Holopainen, M. Prediction of Forest Stand Attributes Using TerraSAR-X Stereo Imagery. Remote Sens. 2014, 6, 3227-3246. [CrossRef]

52. Chand, T.R.K.; Badarinath, K.V.S. Analysis of ENVISAT ASAR data for forest parameter retrieval and forest type classification-a case study over deciduous forests of central India. Int. J. Remote Sens. 2007, 28, 4985-4999. [CrossRef]

53. Persson, H.J.; Olsson, H.; Soja, M.; Ulander, L.; Fransson, J. Experiences from Large-Scale Forest Mapping of Sweden Using TanDEM-X Data. Remote Sens. 2017, 9, 1253. [CrossRef]

54. Olesk, A.; Voormansik, K.; Vain, A.; Noorman, M.; Praaks, J. Seasonal Differences in Forest Height Estimation from Interferometric TanDEM-X Coherence Data. IEEE J. Sel. Top. Appl. Earth Obs. Remote Sens. 2015, 8, 5565-5572. [CrossRef]

55. Saatchi, S.; Ulander, L.; Williams, M.; Quegan, S.; LeToan, T.; Shugart, H.; Chave, J. Forest biomass and the science of inventory from space. Nat. Clim. Chang. 2012, 2, 826. [CrossRef]

56. Persson, H.; Fransson, J. Forest Variable Estimation Using Radargrammetric Processing of TerraSAR-X Images in Boreal Forests. Remote Sens. 2014, 6, 2084-2107. [CrossRef]

57. Wegmüller, U.; Werner, C.L. SAR Interferometric Signatures of Forest. IEEE Trans. Geosci. Remote Sens. 1995, 33, 1153-1161. [CrossRef]

58. Solberg, S.; Weydahl, D.J.; Astrup, R. Temporal Stability of X-Band Single-Pass InSAR Heights in a Spruce Forest: Effects of Acquisition Properties and Season. IEEE Trans. Geosci. Remote Sens. 2015, 53, 1607-1614. [CrossRef]

59. Olesk, A.; Praks, J.; Antropov, O.; Zalite, K.; Arumäe, T.; Voormansik, K. Interferometric SAR Coherence Models for Characterization of Hemiboreal Forests Using TanDEM-X Data. Remote Sens. 2016, 8, 700. [CrossRef]

60. Castillo, J.; Younis, M.; Krieger, G. A HRWS SAR system design with multi-beam imaging capabilities. In Proceedings of the 2017 European Radar Conference (EURAD), Nuremberg, Germany, 11-13 October 2017; pp. 179-182.

(C) 2019 by the authors. Licensee MDPI, Basel, Switzerland. This article is an open access article distributed under the terms and conditions of the Creative Commons Attribution (CC BY) license (http://creativecommons.org/licenses/by/4.0/). 